\title{
KORELASI SEBARAN SUMBER DAYA ARKEOLOGI TERHADAP DAERAH RAWAN BENCANA DI KAWASAN BOROBUDUR
}

\author{
Oleh : \\ Yudi Suhartono, MA \\ Koordinator Pokja Dokumentasi dan Publikasi \\ Balai Konservasi Peninggalan Borobudur
}

Sumberdaya arkeologi atau benda cagar budaya beserta situsnya adalah sisa-sisa hasil budaya fisik peninggalan nenek moyang yang masih dapat dilihat di muka bumi sampai saat ini. Sumberdaya arkeologi tersebut merupakan warisan budaya dan merupakan data yang sangat penting untuk merekontruksi sejarah serta mengetahui proses perubahan masa lalu. Scovil, Gordon dan Anderson (1977 dalam Tjahjono, 1996) mengatakan bahwa sumberdaya arkeologi adalah semua bukti fisik atau sisa budaya yang ditinggalkan oleh

manusia masa lampau pada bentang alam tertentu yang berguna untuk menggambarkan, menjelaskan, serta memahami tingkah laku dan interaksi mereka sebagai bagian yang tidak dapat dipisahkan dari perubahan sistem budaya dan alamnya. Pendapat yang hampir sama juga dikemukan oleh Subroto (1994) yang mengatakan bahwa sumberdaya arkeologi (benda cagar budaya dan situs) merupakan petunjuk bahwa di tempat tersebut pernah dilakukan aktivitas-aktivitas tertentu oleh suatu kelompok masyarakat dan lokasi tempat keberadaannya dapat memberikan gambaran tentang lingkungan alam dan penguasaan teknologi masyarakat pendukung situs tersebut.

Salah satu kawasan yang memiliki banyak mengandung sumberdaya arkeologi adalah kawasan Borobudur yang terletak di kabupaten Magelang, Jawa Tengah. Di kawasan Borobudur terdapat sumberdaya arkeologi yang terkenal di seluruh dunia dan merupakan salah satu world heritage di Indonesia yaitu candi Borobudur. Selain candi Borobudur, juga terdapat sumberdaya arkeologi lain yang tersebar di kawasan tersebut.

Berdasarkan data yang ada di Balai Konservasi Peninggalan Borobudur dan hasil penelitian di lapangan, dapat di ketahui bahwa di kawasan Borobudur terdapat 34 sumberdaya arkeologi dari masa Hindu Buddha dan 2 sumberdaya arkeologi peninggalan Kolonial Belanda serta 2 rumah tradisional Jawa. Sumberdava arkeologi tersebut memiliki nilai penting yang tinggi dari sudut sejarah, ilmu pengetahuan, asosiasi, estetika, arkeologi, ekonomi dan nilai legitimasi.

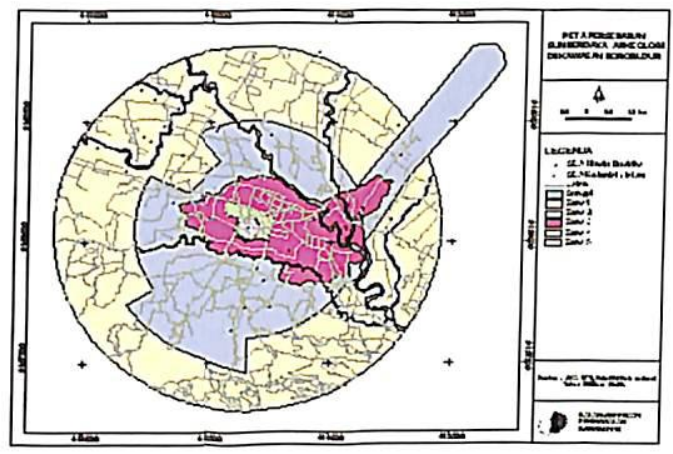

Peta Persebaran Sumberdaya arkeologi di Kawasan Borobudur

Demikian sumberdaya arkeologi harus dijaga dan dilestarikan untuk dapat diwariskan pada generasi berikutnya.

Di lain pihak, Indonesia merupakan wilayah rawan bencana, yang dapat mengancam jiwa manusia, harta benda, infrastruktur termasuk juga sumberdaya arkeologi. Secara fisiologi wilayah Indonesia terdiri atas landas kontinen, cekungan (basin) samudra dan sabuk orogenik (orogenic belt). Secara geologis wilayah Indonesia merupakan tempat pertemuan beberapa lempeng utama kerak bumi, yaitu lempeng Eurasia yang membentang dari barat laut dan utara, berakhir di selatan di Sunda Shelf, lempeng India dan Autaralia yang membentang dari barat dan selatan, berakhir di utara di Sahul Shelf serta lempeng Samudra Pasifik di timur laut. Oleh karena itu wilayah Indonesia Indonesia menjadi rawan terhadap bencana gempa bumi tektonik yang kadang-kadang disertai dengan terjadinya Tsunami (gelombang pasang laut) (Hadiwonggo, 2002:4).

Wilayah Indonesia juga merupakan tempat pertemuan sistem pegunungan utama yaitu

Sistem pegunungan Alpin Sunda, vang membentang dari Himalaya, Arakan Yona (Myanmar), Kepulauan Andaman, Pulau Sumatera, Jawa, Bali, Lombok, Sumbawa, Flores dan berakhir di laut Banda

Sistem pegunungan Asia Timur, sering discbut pula Sirkum Pasifik, yang membentang dari Jepang, Filipina dan berakhir di Sulawesi.

Sistem pegunungan Sirkum

Australia, rang membentang dari
New Zealand, New Celedonia, Papua Nuigini, Irian Jaya dan berakhir di pulau Halmahera Akibat pengaruh perputaran bumi, wilayah Indonesia yang menjadi tempat pertemuan entpat lempeng kerak bumi dan tiga sistem pegunungan utama, terus menerus bergerak yang menyebabkan wilayah Indonesia berwujud kepingankepingan daratan yang membentuk ribuan pulau-pulau besar dan kecil (kurang lebih berjumlah 17.667 pulau). Hal ini juga menyebabkan wilayah Indonesia sangat labil dan rentan akan gempa bumi tektonik, gerakan tanah, tanah longsor

dan erupsi gunung api. Sebagai akibat perputaran bumi itu pula lempeng kerak bumi yang menjadi landasan Kepulauan Indonesia, bergerak (bergeser) antara 6-8 $\mathrm{cm}$ setiap tahun. (Hadiwonggo, 2002: 4).

Melihat kondisi demikian pada wilayah Indonesia, maka perlu dilakukan penanganan yang serius untuk mengurangi dampak yang ditimbulkan oleh bencana yang diperkirakan akan terjadi di Indonesia. Dampak yang ditimbulkan tidak hanya pada jiwa manusia dan harta benda, tetapi juga pada sumberdaya arkeologi, seperti yang terjadi pada gempa bumi tahun 2006 di Jogyakarta yang merusak dan menghancurkan Candi Prambanan, Candi Sojiwan, Taman Sari, Kompleks makam di Imogiri dan sumberdaya arkeologi yang berada di Yogyakarta dan Jawa Tengah.

Untuk meminimalkan dampak yang akan terjadi, maka pada tulisan ini akan dibahas mengenai hubungan sebaran sumberdaya arkeologi dengan daerah rawan bencana yang ada di kawasan Borobudur, yang akan digunakan sebagai dasar untuk melakukan manajemen bencana dikawasan Borobudur

Korelasi Sumberdaya Arkeologi dengan Daearh Rawan Gempa Bumi

Indonesia merupakan negara kepulauan yang menjadi tempat pertemuan antara empat lempeng tektonik bumi yaitu I.empeng Indonesta, I.empene Rurasia, lempeng Pasifik dan Philipina. Darikondisi scismo-tektonik berupa 


\section{Hasil Studi}

interaksi dari lempeng-lempeng yang berbeda jenis tersebut, telah terbentuk jalur subduksi / penunjaman dan jalan tubrukan yang terus aktif, hal ini mengakibatkan kepulauan dan kotakota Indonesia memiliki aktivitas seismik yang tinggi dan mempengaruhi tingkat seismisitas di antara wilayah-wilavah di Indonesia. Jalur penunjaman lempeng Hindia Australia bergerak ke utara relatif terhadap lempeng Eurasia dengan kecepatan rata-rata $7,7 \mathrm{~cm}$ per tahun di pulau Sumatera membuat sudut serong sambil membentuk patahan geser yang dikenal sebagai Patahan Geser Sumatera.

Penunjaman tegak lurus terjadi di sebelah timur mulai dari pulau Jawa, Bali, Nusa Tenggara dalam kecepatan sekitar $7 \mathrm{~cm}$ per tahun. Akibat penunjaman tegak lurus tersebut di sebelah utara pulau-pulau tersebut, terjadi hunjaman balik yang dikenal sebagai Patahan Geser Naik Busur Belakang Flores. Lempeng Pasifik bergerak ke barat relatif terhadap lempeng Hindia - Australia dan lempeng Eurasia. Di Papua lempeng Pasifik berbenturan dengan lempeng kerak benua Australia, sehingga di "Central Range" Irian Jaya terbentuk patahan aktiv di antaranya Jalur Patahan Naik Membramo, "Foreland Frontal Fault", Highland Fold Thrust Belt" dan Patahan Geser Tarera Aiduna (Sangaran, 2007: 2).

Dari gambar persebaran gempa di bawah ini, terlihat bahwa kota-kota di Jawa Tengah termasuk daerah Kedu Selatan merupakan daerah rawan gempa bumi. Di Daerah Kedu Selatan ini terletak kawasan Borobudur. Dilihat dari keletakan, kawasan Borobudur merupakan daerah berbentuk lembah yang di keliling oleh gunng-gunung seperti gunung Merapi, gunung Merbabu, pergunungan Manoreh dan beberapa gunung lainnya. Kawasan Borobudur juga rawan terhadap gempa bumii mengingat kawasan Borobudur terdapat garis sesar yang direka vang ditunjukan pada peta geologi lembar Yogyakarta tahun 1995 yang mencankup kawasan Borobudur. Di lain pihak di kawasan Borobudur terdapat banyak sumberdaya arkenlogi yang tersebar di kawasan Borobudur. Melihat kondisi demikian, perlu dilakukan tindakan pencegahan untuk menyelamatkan sumberdaya arkeologi yang banyak terscbar di kawasan Borobudur dari dampak vang timbul jika terjadi gempa bumi schingga kelestarian sumberdava

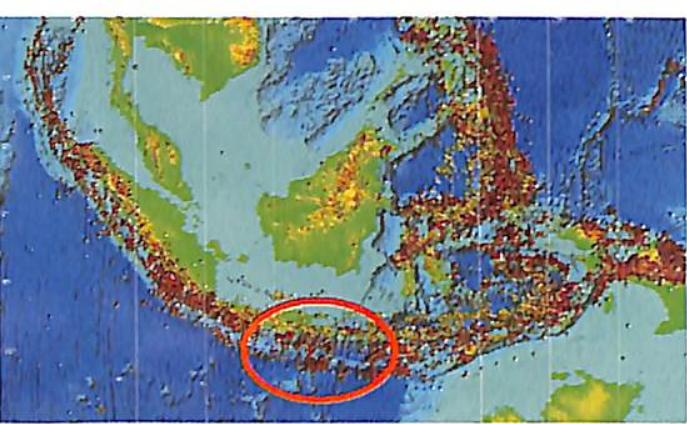

Peta Sebaran Gempa Bumi Tektonik Yang Pernah Terjadi di Indonesia. Titik-titik menunjukkan lokasi yang pernah dan sering terjadi gempa bumi tektonik (Sumber : Karnawati, 2007)

arkeologi dapat terjaga dan dapat diwariskan kepada generasi pada masa mendatang.

Korelasi Sumberdaya Arkeologi Dengan Rawan Gerakan Tanah

Kondisi geografis di kawasan Borobudur yang terdiri pegunungan dan perbukitan menyebabkan kawasan ini sangat rawan terhadap bencana gerakan tanah. Berdasarkan data dari Badan Perencanaan Pembangunan Daerah Kabupaten Magelang tahun 2002, dapat diketahui potensi kerawanan gerakan tanah di kawasan Borobudur, yang terbagi menjadi 4 zona sebagai berikut :

\section{Zona kerawanan Tinggi}

Zona kerawanan tinggi merupakan daerah yang hampir selalu mengalami gerakan tanah apabila terjadi pemicu. Pemicu ini dapat berupa hujan deras atau hujan tidak deras namun turun terus menerus selama lebih dari 2 jam, getaran-getaran, penggalian atau pemotongan lereng, penebangan atau penanaman pohon secara sembarangan dan penambahan beban pada lereng. Zona kerawanan tinggi ini secara umum terletak pada daerah akumulasi air misalnya daerah lereng-lereng pada lembah sungai atau lereng-lereng di sekitar parit alamiah (gully), dengan sudut kemiringan lereng $20^{\circ}-40^{\circ}$ dengan mayoritas lereng mendekati $400^{\circ}$. Iereng-lereng di dacrah tersebut tersusun oleh batuan hasil pengendapan Gunung Sumbing Tua vang berupa batu pasir tufaan yang miring ke arah luar lereng dengan sudut perlapisan lebih kecil dari kemiringan lereng. Selain itu batuan produk Gunung Merbabu Muda berupa batu pasir tuff vang terpotongpotong oleh kekar secara insentif, breksi andesit formasi andesit tua dan batu pasir dengan sisipan lempung Formasi
Nanggulan juga merupakan batuan yang rentan bergerak. Sebagian besar batuan tersebut telah lapuk menjadi tanah lempung dengan ketebalan $>4$ $m$. Rembesan-rembesan atau mata air sering dijumpai pada lereng-lereng dengan kerawanan tinggi meskipun $\mathrm{d}$ musim hujan. Gerakan tanah yang terjadi di zona tersebut umumnya berupa nendatan, luncuran, jatuhan serta tipe komplek (kombinasi) atau rayapan pada lereng yang relatif landai (dengan kemiringan $\leq 20^{\circ}$ ). Di kawasan Borobudur, wilayah masuk zona ini meliputi desa Giri Purwo bagian selatan dan tengah, desa Giri'Tengah bagian selatan dan tengah, desa Majaksingi, desa Ngargogondo bagian selatan, desa Candirejo bsgian selatan, desa Kenalan, desa Sambeng, desa Kebonsari, dan sepanjang sungai besar.

Sumberdaya arkeologi yang masuk dalam zona ini adalah situs Pekem (PAK) dan situs-situs di tepi sungai-sungai besar seperti situs-situs di sekitar Mendut dan situs Gedongan.

\section{Zona Kerawanan Menengah}

Zona kerawanan menengah merupakan zona yang kadang-kadang mengalami gerakan tanah apabila terjadi pemicu, setelah hujan deras, penggalian / pemotongan lereng, penanaman atau penebangan pohon secara sembarangan dan pembebanan yang berlebihan pada lereng. Zona kerawanan menengah tersebut terletak pada daerah dengan kemirigan lereng $20^{\circ}-40^{\circ}$ dengan mavoritas lebih mendekati kemiringan lereng $20^{\circ}$. Lereng-lereng tersusun oleh berbagai jenis batuan produk gunung api tua hingga muda, yaitu batu pasir tufaan, tuf pasiran dan breksi andesit dari gunung Sumbing; breksi tuf dan lava dari Gunung Merbabu; tuf, breksi aglomerat dan lava dari Gunung Merapi serta andesit dari Formasi Andesit Tua. Batuan tersebut scbagian besar telah lapuk menjadi tanah pasir lempungan dengan ketebalan $2 \mathrm{~m}-4$ m. Tata guna lahan umumnya berupa hutan dan kebun campuran. Gerakan tanah terjadi di zona tersebut berupa nendatan, jatuhan serta tipe komplek (kombinasi) dan rayapan.

Di kawasan Borobudur, wilayah yang masuk zona ini meliputi sebagian besar desa Ngadiharjo, bagian barat desa kiebon Sari, bagian utara desa (iri Purwo, Giri Tengah dan Majaksingi. Bagian selatan Desa Kembang limus, Karanganyar dan Candirejo, bagian tengah desa Kenalan, dan Sambeng. 
Sumberdaya arkeologi yang masuk dalam zona ini adalah Situs Malangan (MAL) dan situs Kiyudan (KRJ).

\section{Zona Kerawanan Rendah}

Zona kerawanan rendah merupakan daerah yang jarang mengalami gerakan meskipun terjadi pemicu. Zona ini terletak pada daerah dengan kemiringan lereng $10^{\circ}-20^{\circ}$ dan lereng-lereng tersebut tersusun oleh endapan aluvial, breksi vulkanik, lava andesit, batuan yang tersingkap keras dan masif dengan ketebalan tanah pelapukan $1 \mathrm{~m}-2 \mathrm{~m}$, tata guna lahan umumnya berupa hutan dan kebun campuran. Gerakan tanah terjadi di zona tersebut umumnya berupa rayapan massa tanah lempung pasiran melalui bidang rayapan yang berupa lapisan batu lempung lunak dan sensitif berkembang saat jenuh air.

Di kawasan Borobudur, wilayah masuk zona ini meliputi bagian barat laut desa Ngadiharjo, desa Karangrejo dan desa Kembanglimus. Dalam wilayah zona ini tidak ada sumberdaya arkeologi.

\section{Zona Kerawanan Sangat Rendah}

Zona kerawanan sangat rendah merupakan zona yang sangat jarang atau hampir tidak akan mengalami gerakan. Zona tersebut secara umum terletak pada daerah dengan kemiringan lereng $0^{\circ}-10^{\circ}$ dan tersusun oleh endapan aluvial yang berupa pasir lempungan, batuan yang tersingkap sangat keras dan masif, ketebalan tanah pelapukan $<1 \mathrm{~m}$, tata guna lahan umumnya berupa hutan, pemukiman penduduk dan sawah. Gerakan tanah terjadi di zona tersebut umumnya jarang terjadi.

Di kawasan Borobudur, wilayah masuk zona ini meliputi sebagian besar desa Tegalarum, Wringin Putih, Bumiharjo, Borobudur, Tanjung Sari dan Tuksongo. Bagian utara desa Kebonsari, Karanganyar, Majaksingi, Ngargogondo dan Candirejo. Untuk sumberdaya arkeologi sebagian besar masuk dalam zona ini seperti candi Borobudur, candi Pawon, situs Dipan, Brongsongan dan beberapa situs lainya.

\section{Korelasi Sumberdaya Arkeologi} Dengan Rawan Gunung Api

Kawasan Borobudur berada pada ketinggian 265 meter dpl dan pada bentang alam berupa dataran berbukit di wilayah Kedu. Di sebelah timur dataran ini terdapat Gunung Merapi dan Gunung
Merbabu, di sebelah barat laut terdapat Gunung Sumbing dan Sindoro, sedangkan Pegunungan Menoreh membatasi daerah ini dari barat sampai selatan

Di antara Gunung Api tersebut Gunung Merapi dengan ketinggian $\pm 2.968 \mathrm{~m} \mathrm{dpl}$ (daei permukaan air laut) adalah gunung api aktif yang sering menimbulkan bencana alam bẹrupa letusan. Gunung Merapi boleh dikatakan selalu aktif sejak tahun 1,822 sampai denga sekarang terjadi 33 kali erupsi dengan periode diam atau istirahat yang pendek (rata-rata tidak lebih dari 3,5 tahun) (Yusup, 2006 : 3). Erupsi Gunung Merapi banyak menimbulkan bencana mulai tahun 1672 tercatat 5.691 koban jiwa, 1480 rumah hancur dan 2.218 ternak mati, belum termasuk korban akibat bencana lahar. Erupsi terbesar abad 20 terjadi pada tahun 1930 menimbulkan 1.369 korban jiwa, 1.109 rumah hancur dan 2.140 ternak mati. Erupsi terakhir yang menimbulkan bencana terjadi pada tahun 1994 dengan korban jiwa 64 jiwa dan 25 rumah hancur (Kusumadinata, 1979 dalam Yusup, 2006:4)

Bahaya Gunung Api dibedakan menjadi bahaya primer dan bahaya sekunder (Smith, 1996, Stieltjes and Wagner, 1999, Wright et al. 1992, Crandell, 1984 dalam Yusuf, 2006: 15) Bahaya Primer atau bahaya langsung didasarkan pada dampak langsung dari hasil-hasil erupsi, meliputi aliran lava (lava flows), aliran piroklastik (pyroclastic flow), bahan jatuhan (free-fall deposits) dan gas. Bahaya sekunder atau bahaya tidak langsung didasarkan pada akibat sekunder dari erupsi meliputi lahar, gerakan massa (slumps, slides, subsidence, block falls, debris avalanche), tsunami dan hujan asam / hujan abu.

Berdasarkan peta daerah rawan Gunung Merapi yang dikeluarkan oleh Direktorat Vulkanologi, kawasan Borobudur berada diluar kawasan bahaya Gunung Merapi, namun demikian, dampak dari aktivitas Gunung Merapi juga terasa hingga Borobudur. Salah contoh adalah aktivias Gunung Merapi pada bulan Juni tahun 2006 menyebabkan menyebabkan hujan abu di sekitar Gunung Merapi termasuk menjangkau kawasan Borobudur. Hujan abu yang terjadi menyebabka batu-batu candi Borobdur tertutup oleh abu vulkanik Gunung Merapi

\section{Mitigasi Bencana di Kawasan Borobudur}

Mitigasi (penjinakan) adalah segala upaya dan kegiatan yang dilakukan akibat-akibat yang ditimbulkan oleh bencana, yang meliputi kesiapsiagaan serta penyiapan kesiapan fisik, kewaspadaan dan kemampuan (Depdagri, 2003 dalam Sutikno, 2007). Menurut Adrisijanti (2007) mitigasi adalah upaya yang dilakukan untuk mengurangi dampak bencana, baik secara fisik struktural melalui pembuatan bangunan-bangunan fisik, maupun non fisik struktural melalui perundangan-perundangan dan pelatihan.

Untuk menghadapi bahaya bencana alam yang timbul di kawasan Borobudur, perlu dilakukan manajeman mitigasi bencana dengan langkah-langkah sebagai

Pemahaman terhadap karesteristik bahaya bencana alam

Dengan di ketahui pemahaman terhadap karesteristik terhadap bahaya bencana alam, diharapkan adanya kesiapan untuk menghadapi bencana alam yang di kawasan Borobudur

Pendataan dan pemetaan daerah rawan bencana yang ada di kawasan Borobudur

Hasil dari pendataan dan pemetaan daerah rawan bencana ini sangat berguna untuk mengetahui kondisi lingkungan sumberdaya arkeologi yang masuk dalam daerah rawan bencana, sehingga dapat dilakukan persiapan dan perkuatan struktural bagi sumberdaya arkeologi yang memiliki nilai penting yang sangat tinggi.

Melakukan sosialisasi kepada masyarakat tentang daerah rawan bencana yang ada di sekitar mereka, sehingga masyarat dapat mengantisipasi jika timbul bencana alam yang akhirnya dapat memperkecil korban dan kerusakan yang timbuk termasuk kerusakan pada sumbedaya arkeologi.

Monitoring Sumberdaya arkeologi

Perlu dilakukan monotoring pada sumberdaya sehingga dapat diketahui jika terjadi kerusakan akibat bencana alam

Pemasangan alat peringatan dini pada beherapa tempat yang memiliki kerawanan tinggii, jika terjadi bencana alam

Penetapan peraturan tata ruang secara ketat untuk mencegah perusakan lingkungan di kawasan Borobudur, yang mempengaruhi teriadinva bencana alam.

Untuk menghindari terjadinva bahava gerakan tanah dan longsor perlu dilakukan tindakan pencegahan antara lain dapat dilakukan dengan dua cara yaitu cara mekanik dan n 
vegetatif Cara Mekanik adalah perlakukan fisik mekanik yang dikerjakan dengan tujuan mengurangi gaya pendorong atau menambah gaya penahan dari massa tanah atau batuan yang mengalami longsor. Metode penanggulangan longsor secara mekanik yang dapat dilakukan adalah mengubah geometri lereng, penambatan dan pengendalian air rembesan. Cara Vegetatif adalah penamaan pohon tertentu yang bersifat konservatif pada kelerengan tertentu, dan penerapan cara bercocok tanam yang tepat untuk dilakukan pada daerah berbukit atau bergunung atau lereng-lerengnya yang berpotensi longsor dengan tujuan untuk menjaga kestabilan lereng. Tanaman yang digunakan harus memiliki kemampuan mengikat agregat tanah yang kuat sehingga tidak mudah bergerak dan relatif ringan (tidak membebani lahan), dan mampu menyimpan air dalam jumlah yang cukup banyak serta mampu menguapkan air relatif cepat. Dengan demikian tanah tidak mendapat beban berlebih akibat suplai air hujan dan beban tanaman. Tanaman pelindung yang digunakan juga harus disesuaikan dengan kemampuan lahan setempat dan diusahakan merupakan tanaman yang mudah dibudidayakan (Santoso, et.al., 2004, dalam Adibrata, 2007: 126).

\section{Mitigasi Bencana Gempa Bumi di Candi Borobudur}

Candi Borobudur sebagai salah satu candi terbesar di dunia dan memiliki nilai penting yang sangat tinggi, merupakan salah satu daerah kunjungan wisata di Indonesia dan banyak dikunjungi dikunjungi oleh wisatawan baik wisatawan nusantara maupun wisatawan macam negara. Dari data pengunjung, dapat diketahui kunjungan wisatawan setiap tahun ke candi tersebu lebih dari 1 juta orang. Melihat kondisi demikian jika terjadi bencana alam seperti gempa bumi, yang menjadi korban, tidak hanya pada candi Borobudur sebagai sumberdaya arkeologi tetapi juga wisatawan yang mengunjungi candi tersebut. Untuk itu, perlu dilakukan manajemen mitigasi bencana gempa bumi pada candi tersebut untuk menghindari dan mengurangi kerusakan dan korban yang timbul jika pada suatu saat jika terjadi bencana gempa bumi. Langkah-langkah yang dapat dilakukan dalam konteks manajernen mitigasi bencana di candi
Borobudur sebagai berikut :

1. Memperkuat struktur bangunan candi Borobudur yang meliputi struktur pondasi untuk menahan getaran jika terjadi gempa bumi; dan struktur komponen-komponen arsitektur pada candi tersebut sehingga bila ada gempa bumi tidak mudah runtuh dan jatuh mengenai wisatawan.

2. Mempersiapkan jalur evakuasi dan tempat yang aman untuk mengevakuasi pengunjung jika terjadi gempa bumi.

3. Memberikan informasi kepada wisatawan mengenai hal-hal yang berkaitan dengan gempa bumi dan apa yang diharuskan jika terjadi gempa bumi sehingga pada diri setiap wisatawan mempunyai kesiapan dan kesiagaan dalam menghadapi gempa bumi. Jika hal ini telah dilakukan akan mempermudah dalam melakukan evakuasi.

4. Memberi tanda-tanda arah di mana jalur dan tempat evakuasi pada wisatawan

5. Memasang alat peringatan dini jika terjadi gempa bumi di Candi Borobudur

6. Mempersiapakan dan melatih tenagatenaga yang siap membantu dan mengarahkan wisatawan jika terjadi gempa bumi.

\section{Penutup}

Di kawasan Borobudur terdapat losasi yang rawan terhadap bencana alam gempa, gerakan tanah dalam hal ini longsor dan bencana gunung api (gunung Merapi). Untuk daerah rawan gampa bumi, seluruh sumberdaya arkeologi rawan terhadap ancaman gempa bumi. Hal ini disebabkan gempa bumi bisa terjadi di mana saja tanpa diduga termasuk di kawasan Borobudur. Sedangkan untuk daerah rawan bencana longsor, sebagian besar sumberdaya arkeologi termasuk dalam katagori kerawanan sangat rendah dan aman dari arcaman bencana longsor. Hanya ada beberapa sumberdaya arkologi yang masuk kategori kerawanan sangat tinggi dan menengah, namun sumberdaya arkeologi tersebut, hanya berupa temuan lepas.

Kawasan Borobudur tidak termasuk dalam wilayah zona 1 dan zona 2 daerah rawan bencana gunung Merapi, akan tetapi dampak sckunder aktivitas gunung Merapi berupa hujan abu sangat mengganggu kelestarian sumberdava arkeologi yang ada. Untuk menghadapi ancaman bahaya bencana alam pada sumberdaya arkeologi dan lingkungannya, perlu diambil langkah-langkah pencegahan berupa manajemen mitigasi bencana sehingga akan timbul kesiapan dan kesiagaan dalam menghadapi ancaman bencana alam. 凶

\section{Daftar Pustaka}

Adibrata, Ambarini $2007 \quad$ "Bahaya Longsor Pada Situs-situs Arkeologi di Pegunungan Baturagung Daerah Istimewa Yogyakarta" Tesis Program Studi Geografi Program Pasca Sarjana UGM.

Hadiwonggo, Hernowo 2002 “Strategi Mitigasi Bencana Dalam Rangka Perlindungan dan Pelestarian Benda Cagar Budaya, Museum dan Situs Berdasarkan Manajemen Bencana" Makalah pada Pendidikan Manajemen Siaga Bencana Benda Cagar Budaya, Museum dan Situs. Jakarta : Badan Pengembangan Kebudayaan dan Pariwisata..

Karnawati, Dwikorita, 2007 "Antisipasi Bahaya Geologi Dalam Konteks Tata Ruang" Makalah dalam Seminar Nasional Manajemen Bencana dalam Konteks Tata Ruang. Yogyakarta : IMPI UGM

Subroto, Ph. 1994. "Pola-pola Zonal Situs-situs Arkeologi", dalam Berkala Arkeologi Manusia dalam Ruang : Studi Kawasan dalam Arkeologi. Tahun XVI, edisi Khusus. Yogyakarta : Balai Arkeologi

Tjahjono, Baskoro Daru, 1996 "Pemikiran Inklusif Atas Dampak Pembangunan Terhadap Kelestarian Sumberdaya Arkeologi" Berkala Arkeologi No. 1 Tahun XVI. Jogyakarta: Balai Arkelogi

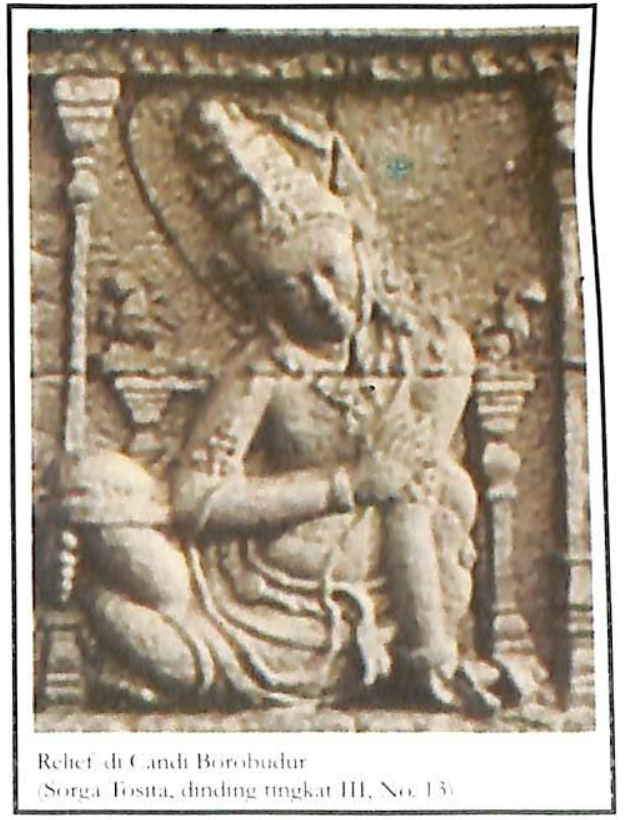

